\title{
LOS TABARQUINOS
}

\author{
ÓSCAR FERNÁNDEZ ALVAREZ
}

\section{Resumen:}

Este trabajo presenta tres partes: la geografía, la historia del pueblo tabarquino, desde los orígenes hasta el siglo XX, y después se estudia el universo de la cultura tradicional de esta comunidad isleña.

\section{Palabras clave}

Antropología de la pesca. Parentesco, Historia Oral, Antropología del Mediterráneo.

\begin{abstract}
This paper shows three related parts: the Tabarca village, Geography, origins and History towards the twentieth Century, and then, an analyse of the traditional culture of this islander community.
\end{abstract}

\section{Key words}

Fishing Anthropology, Kinship, Oral History, Mediterranean Anthropology.

La década que comienza en 1970, fue la época del comienzo de la realización de las grandes monografías dentro del panorama antropológico español. Unas realizadas por antropólogos españoles, y otras por antropólogos extranjeros, algunas se convirtieron rápidamente en clásicas. Esta época marca el inicio del asentamiento académico de la disciplina antropológica en la Universidad española.

Este es el contexto en el que se fragua la obra que aquí nos ocupa. La segunda edición de Los Tabarquinos, de José Luis González Arpide, participa de los errores y logros de los iniciadores, y de los avances y concreciones que permite la perspectiva del tiempo transcurrido.

El libro está dividido en tres partes: una geográfica, otra histórica y una tercera etnográfica más un anexo complementario. El autor se plantea, dar a conocer quiénes son los Tabarquinos que habitan en una pequeña isla de la costa mediterránea. En él se recogen diversos aspectos de la vida tradicional de los isleños: así se describen las técnicas relacionadas con una agricultura incipiente 
y la recolección de productos tanto marinos como terrestres que reflejan los años de escasez y penurias pasados en la isla. En cuanto a la economía pesquera se recogen de forma exhaustiva las diferentes técnicas de pesca, tanto fijas como de deriva, de cerco y de arrastre, los tipos de anzuelos y redes, las trampas y las especies marinas del fondo litoral de la isla, se complementa con información de artes desaparecidas, oficios relacionados con la pesca y la economía pesquera tradicional.

En el aspecto social se recogen las costumbres derivadas del nacimiento, matrimonio y defunción. Los datos descriptivos recogidos en este capítulo surgen de la utilización del Cuestionario del Ateneo, lo cual no deja de tener interés por la posibilidad que ofrece de comparación con los datos de la época. Este cuestionario, elaborado por R. Salillas, J. Puyol, C. Bernaldo de Quirós y otros, en 1901, lleva la impronta de la Institución Libre de Enseñanza y de Joaquín Costa. Partía Costa de que el espíritu popular se manifestaba en las convenciones y en las normas políticas, jurídicas locales: de ahí la necesidad de recoger in situ estas regulaciones. El medio para lograrlo era la confección de cuestionarios que proveyeran a los investigadores de una marco de referencia. Las respuestas al cuestionario recogidas por toda España, en su mayor parte, han permanecido en el olvido desde entonces, y es ahora, un siglo después, cuando se están empezando a publicar.

Se completa el capítulo etnográfico de Los Tabarquinos con un estudio de parentesco y otro peculiar sobre los grupos sanguíneos de los tabarquinos. Se recoge igualmente, el ciclo festivo haciendo especial énfasis en el de las fiestas religiosas, con aportación de datos de tradición oral, incluida música popular cuya trascripción musical se acompaña. Como todo este bloque ha sido realizado mediante trabajo de campo, se incluyen, en apartado final, los datos de los informantes que facilitaron los datos. Con las láminas se completa de forma visual los tipos de pesca y redes, los nudos y anzuelos, instrumental de los carpinteros de ribera, las diversas partes de los barcos, en construcción y los barcos antiguos, también se incluyen tipos de ánforas romanas encontradas en las excavaciones y el tipo de vivienda tradicional. Termina el trabajo con una exhaustiva bibliografía actualizada, cartografía y artículos de prensa así como los agradecimientos correspondientes.

Nos encontramos ante una obra que intenta articular los aspectos históricos con los etnográficos, una obra que se sitúa entre la historia y la etnohistoria, tratando de darnos una visión lo más completa tanto de su sociedad como de los diversos y variados hechos que han llegado a conformarla. "Resulta paradójico" dice el autor, "que los datos de tipo etnográfico, se han convertido casi en 
históricos porque reflejan más un pasado que un presente". "Pero no nos dejemos engañar", continúa, "los pueblos suelen buscar sus raíces y las generaciones más jóvenes pueden comparar y saber quienes son hoy gracias a sus mayores y lo que estos les legaron".

En el apartado etnográfico, el autor ha ensayado, con excelente resultado, lo que el mismo denomina un estudio de microantropología, es decir con una porción de habitantes lo mas amplia posible, se ha extraído el máximo de información. Al describir minuciosamente desde los aparejos de la pesca y las especies de la fauna marina, hasta el instrumental de los carpinteros de ribera, nos aproxima a realidades, muchas de ellas ya desaparecidas, convirtiéndose la información en datos etnohistóricos. Quizá el contrapunto sea que la comunidad en su conjunto queda desdibujada ante tanta especifidad de la tecnología pesquera. Contribuye a ello la utilización del cuestionario antes mencionado, que estructurado en bloques, se divide y subdivide en grandes en apartados cada vez más concretos, creando excesiva rigidez en la descripción.

Las manifestaciones de carácter oral, religioso y musical que han desaparecido en su gran medida, quedan aquí recogidas como testimonio muy cercano cronológicamente, pero transformados en la dinámica de los nuevos tiempos al servicio del turismo. El análisis de parentesco y relaciones familiares y sus grupos sanguíneos ofrece el interés por constatar como, las familias instaladas han tenido tranquila continuación. Aquí el autor participa del síndrome del enterrador y del que también tenemos referencias en otras obras suyas. Las sociedades cambian, evolucionan y se transforman, aunque, con frecuencia, es difícil saber hacia qué dirección. En definitiva, hay toda una serie de elementos que hacen de Los Tabarquinos una obra única en su especie. Los cincuenta y dos informantes isleños, entre hombres y mujeres ofrecen, a través de este trabajo, un panorama rico, complejo y variado de una porción de tierra pequeña a la que el autor ha sabido sacarle el máximo rendimiento. 